\title{
ANALISA PERBANDINGAN BEBAN KERJA MENGGUNAKAN KOMPRESOR TUNGGAL DAN DUA KOMPRESOR DENGAN SISTEM EXPANSION VALVE PADA COLD STORAGE PENYIMPANAN UDANG KALENG
}

\author{
${ }^{(1)}$ Sobar Ihsan, ${ }^{(2)}$ Rendi \\ (1)(2)Program Studi Teknik Mesin, Universitas Islam Kalimantan MAAB \\ Jl. Adhyaksa no. 2 kayutangai banjarmasin \\ Email :sobar.uniska@gmail.com, rendi.teknikmesin@gmail.com
}

\begin{abstract}
Abstrak
Cold Storage merupakan suatu mesin refrigerasi yang digunakan untuk menyimpan suatu produk dalam suhu tertentu, sehingga kualitas produk tetap terjaga. Analisa teknis di lakukan dengan menganalisa parameter- parameter : Thermodynamic Refrigeration Cycle, Refrigerant effect $(R E)$, Laju aliran massa(m) dan Kerja kompresi (W) dari masing-masing tipe, setelah memperoleh karakteristik teknis dapat di hitung daya yang dibutuhkan oleh masing-masing tahapan (chilling, freezer dan.storage). Daya total yang dibutuhkan oleh ketiga tahapan tersebut akan dibandingkan terhadap kedua alternatif. Analisa ekonomis dilakukan dengan membandingkan biaya yang dibutuhkan sesuai hasil analisa teknis baik dari sisi konstruksi desain maupun penggunaan energi listrik yang dibutuhkan dari kedua tipe tersebut.

Setelah melakukan analisa teknis dan ekonomis terhadap kedua tipe. dari hasil perhitungan teoritis ternyata ada perbedaan total daya kompresor yang dibutuhkan antara model satu kompresor dan dua kompresor, pada model satu kompresor daya total kompresor adalah $121075 \mathrm{Btu} / \mathrm{jam}$, sedangkan pada model kedua dengan dua kompresor daya total kompresor yang dibutuhkan adalah 196304,4 Btu/jam, berarti ada selisih sebesar 75229,4 Btu/jam atau 21,3 KW, secara ekonomis dengan memakai model dua kompresor maka dapat dilakukan penghematan sebesar : 21,3 KW x 24 jam x 365 hari.
\end{abstract}

Kata kunci : Cold Storage, Kompresor, Sistem Expansion valve

\begin{abstract}
Cold Storage is a refrigeration machine that is used to store a product at a certain temperature, so that product quality is maintained. Technical analysis is done by analyzing the parameters: Thermodynamic Refrigeration Cycle, Refrigerant effect (RE), Mass flow rate (m) and Compression work (W) of each type, after obtaining technical characteristics can be calculated the power needed by each - each stage (chilling, freezer and storage). The total power needed by the three stages will be compared against the two alternatives. Economic analysis is done by comparing the costs required in accordance with the results of technical analysis both in terms of design construction and the use of electrical energy needed from both types.

After conducting technical and economic analysis of both types. From the results of theoretical calculations it turns out there is a difference in the total compressor power
\end{abstract}


needed between the models of one compressor and two compressors, in the model of one compressor the total compressor power is $121075 \mathrm{Btu} /$ hour, whereas in the second model with two compressors the total compressor power needed is $196304.4 \mathrm{Btu} /$ hour, meaning there is a difference of $75229.4 \mathrm{Btu} /$ hour or $21.3 \mathrm{KW}$, economically using the two compressor model, savings can be made: $21.3 \mathrm{KW}$ x 24 hours x 365 days.

Keywords : Cold Storage, Compressors, Expansion valve systems

\section{PENDAHULUAN}

Perkembangan teknologi di bidang refrigerasi dan pengkondisian udara mengalami kemajuan dengan pesat seiring berkembangnya zaman. Teknologi refrigerasi memberikan banyak keuntungan bagi manusia. Salah satu penggunaan sistem refrigerasi adalah manusia untuk industri penyimpanan dan pendistribusian produk diagnostik. Sehingga produk diagnostik yang disimpan dengan sistem refrigerasi tersebut dapat terjaga kualitasdan kesegarannya sampai waktu yang lama dan saat diperlukan untuk didistribusikan kepada konsumen.

Pengkondisian udara pada suatu ruang mengatur mengenai kelembaban, pemanasan dan pendinginan udara dalam ruangan. Pengkondisian ini bertujuan memberikan kenyamanan, sehingga mampu mengurangi keletihan yang efeknya untuk meningkatkan kebugaran. Sistem pengkondisian udara pada suatu ruang umumnya terdiri dari evaporator, kondensor, receiver dan kadangkadang dilengkapi elemen pemanas yang tergabung menjadi satu dalam evaporator housing.

Penentuan jenis dan tipe sistem pendingin yang akan di pilih sangat ditentukan karakteristik ikan yang akan di simpan, Jenis ikan lokal yang di konsumsi di Pulau Ambon terdiri atas beberapa jenis, secara teori tiap jenis memerlukan suhu pendinginan/pembekuan yang berbeda. Desain Sistem pendingin dirancang dalam bentuk cold storage dengan tiga tingkatan atau proses yang dilakukan untuk mencapai produk akhir yang bersuhu $-25^{\circ} \mathrm{C}$. Proses tersebut adalah : Optimalisasi desain komponen utama cold storage sangat tergantung pada dua faktor yaitu : faktor teknis dan ekonomis, Pemilihan jenis dan tipe kompresor sebagai salah satu komponen utama dari sistem refrigerasi akan sangat berdampak pada ekonomisnya desain.

Dalam desain ini ditawarkan dua tipe kompresor type reciprocating yang akan di gunakan yaitu : Kompresor sistem tunggal dan dua kompresor dengan sistem expansion valve. Penelitian ini bertujuan melakukan analisa perbandingan secara teknis dan ekonomis, mana dari dua tipe yang ditawarkan ini yang paling ekonomis bila digunakan.

\section{METODE PENELITIAN}

Agar penelitian dapat berjalan secara sistematis, maka diperlukan rancangan penelitian / langkah-langkah dalam penelitian. Adapun flowchart penelitian sebagai berikut :

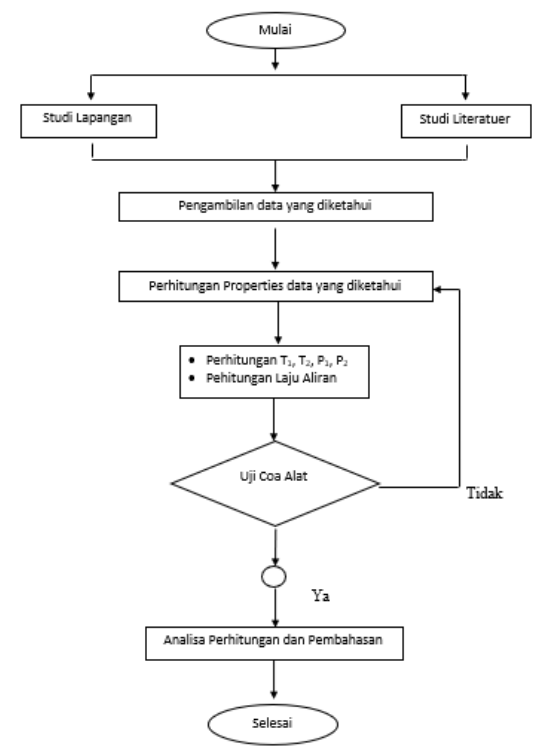

Gambar 1. Alur penelitian 


\section{HASIL DAN PEMBAHASAN 1. Penentuan Dimensi Cold Storage}

Penentuan dimensi dan tata letak cold storage sangat tergantung dari sistem pendingin yang di rancang dan kapasitas cold storage. Sesuai hasil analisa sebelumnya telah ditentukan bahwa : sistem pendingin cold storage dirancang tiga tingkatan (chilling, freezer dan storage) dan kapasitas chilling 25 ton, kapasitas freezing 25 ton dan kapasitas storage adalah 50 Ton/hari. Berdasarkan data dimensi ukuran ratarata jenis- jenis udang yang menjadi konsumsi lokal dan volume udang yang akan desain ukuran dimensi cold storage yang direncanakan :

Ukuran chilling room :

Panjang $=12 \mathrm{~m}$, Lebar $=5 \mathrm{~m}$ dan

Tinggi $=3 \mathrm{~m}$

Ukuran freezing room :

Panjang $=12 \mathrm{~m}$,Lebar $=5 \mathrm{~m}$ dan Tinggi $=3 \mathrm{~m}$

Ukuran storage room :

Panjang $=20 \mathrm{~m}$, Lebar $=5 \mathrm{~m}$ dan Tinggi $=3 \mathrm{~m}$

\section{Perhitungan Beban Pendingin}

Perhitungan beban pendingin dari suatu sistem refrigerasi secara umum terdiri dari : Perhitungan Beban Produk diperoleh dengan rumus (Dossat 1997)

$$
Q_{1}=\frac{m \cdot c_{1}\left(t_{1}-t_{f}\right)}{\text { time }} \times 24 \mathrm{jam}
$$

Dimana :

$\mathrm{Q}_{1}$ : Jumlah panas yang dilepaskan (Btu)

$\mathrm{m}$ : berat produk $(\mathrm{Lb})$

$\mathrm{c}_{1}$ : Panas spesifik diatas freezing $\left(\mathrm{Btu} / \mathrm{Lb}^{\circ} \mathrm{F}\right)$ : 0,84 (pada suhu $20^{0} \mathrm{C}$ )

$\mathrm{t}_{1}$ : Temperatur awal produk diatas suhu freezing : $68^{\circ} \mathrm{F}$

$\mathrm{t}_{2}$ : Temperatur terendah diatas suhu freezing $\left({ }^{\circ} \mathrm{F}\right): 32$ ${ }^{\circ} \mathrm{F}$, di peroleh :

$\mathrm{Q}_{1}=6652800 \mathrm{Btu} / 24 \mathrm{jam}$ (suhu $20^{0}$

ke $0^{0} \mathrm{C}$ ),

$\mathrm{Q}_{2}=1267200 \mathrm{Btu} / 24 \mathrm{jam}$ (chilling

ke freezing)
$\mathrm{Q}_{3}=880000 \mathrm{Btu} / 24 \mathrm{jam}$ (freezing)

dan

$\mathrm{Q}_{4}=1584000 \mathrm{Btu} / 24 \mathrm{jam}($ Storage $)$

\section{Perhitungan beban Pendingin} Internal

a. Beban lampu : beban lampu direncanakan sekecil mungkin, : chilled room (10 W,3 buah), ,Freezing room(10W ,2 buah), storage room (20 W 4 buah).

Maka :

$\mathrm{Q}_{\mathrm{L}}=$ Watt $\times 3.42 \mathrm{Btu} /$ watt jam $\times 24$ jam

$=10670 \mathrm{Btu} / 24 \mathrm{jam}$ (beban total)

b. Beban electric motor : direncanakan electric motor dengan daya $3 \mathrm{hp}$, maka dari tabel (Dossat 10-8), didapatkan jika motor berada diluar ruangan adalah 1150 Btu per jam HP. maka :

Panas yang dilepaskan = beban $\mathrm{x} \mathrm{Hp}$ $\mathrm{x} 24 \mathrm{jam}=82800 \mathrm{Btu} / 24 \mathrm{jam}$

c. Perhitungan beban pekerja : diasumsikan 4 jam sehari dengan 4 orang pekerja

$\mathrm{Q}_{\mathrm{h}}=$ Faktor (tabel) $\mathrm{x}$ jumlah pekerja $\mathrm{x}$ jumlah jam

$=20800 \mathrm{Btu} / 24 \mathrm{hr} ;$ Untuk

Chilling room,

$=24000 \mathrm{Btu} / 24 \mathrm{hr} \quad ;$ Untuk

freezing room,

$=24800 \mathrm{Btu} / 24 \mathrm{hr} \quad ;$ Untuk storage room.

\section{Perhitungan Beban Panas Akibat} Infiltrasi

Dari tabel entalpi didapatkan harga entalpi untuk masing masing kondisi,maka diperoleh Beban infiltrasi tiap ruangan adalah :

$\begin{array}{lll}\text { Chilled room } & & 64732.75 \\ \text { Btu/24 hr } & & \\ \begin{array}{l}\text { Freezing room } \\ \text { Btu/24 hr }\end{array} & 75601.44 \\ \begin{array}{l}\text { Storage room } \\ \text { Btu } 24 \mathrm{hr}\end{array} & & 48575.44\end{array}$


5. Perhitungan Beban Panas Transmisi

Beban kalor yang diakibatkan oleh panas yang ditransmisian kedalam ruang pendingin akibat dari perbedaan suhu antara cold storage dengan udara luar. konstruksi dinding adalah sebagai berikut Susunan dari kontruksi untuk seluruh dinding cold storage adalah sebagai berikut :

\section{Beban Transmisi dari Dinding}

Dari gambar 4.1. didapatkan koefisien perpindahan panas konveksi, dengan konversi $1 \mathrm{Btu} / \mathrm{h}$ per square foot per $\mathrm{F}=5,6 \mathrm{~W} / \mathrm{m}^{2} \mathrm{~K}$.

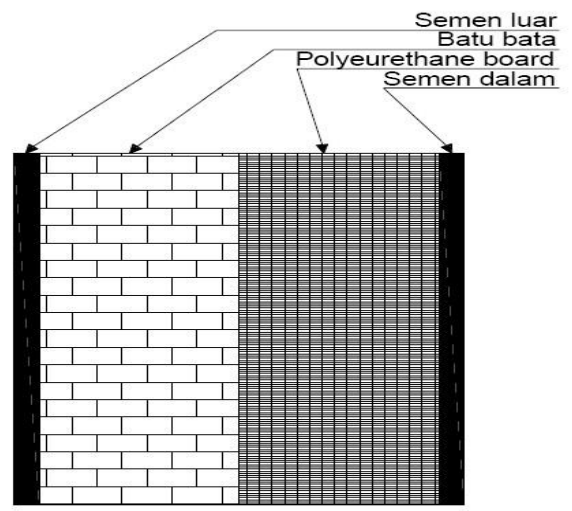

Gambar 2. Konstruksi dinding

Maka didapat bahwa fi $=9,24 \mathrm{~W} / \mathrm{m}^{2} \mathrm{~K}$ dan fo $=22,4 \mathrm{~W} / \mathrm{m}^{2} \mathrm{~K}$.

Dengan persamaan :

$\mathrm{Q}=\mathrm{A} \times \mathrm{U} \times \Delta \mathrm{T}$

Sehingga diperoleh :

$$
\begin{aligned}
U & =\frac{1}{\frac{1}{22,4}+\frac{0,0005}{31,5}+\frac{0,075}{0,046}+\frac{0,0005}{31,5}+\frac{1}{9,24}} \\
& =0,559 \mathrm{~W} / \mathrm{m}^{2} \mathrm{~K}
\end{aligned}
$$

\section{Luas dinding bagian kanan dan kiri}

$\mathrm{L} \quad=\mathrm{p} \times 1$,

$\mathrm{L}$ a dan $\mathrm{b}=2 \times 3 \times 3=18 \mathrm{~m}^{2}$

\section{Luas dinding bagian depan dan} belakang

$\mathrm{L} \quad=\mathrm{p} \times 1$

Luas c dan $\mathrm{d}=2 \times 5 \times 3=30 \mathrm{~m}^{2}$

Luas dinding total $=48 \mathrm{~m}^{2}$

$\Delta \mathrm{T} \quad=\left(\mathrm{t}_{\mathrm{O}}-\mathrm{t}_{\mathrm{i}}\right)$

$t_{0}$ : temperatur luar ; $\mathrm{t}_{\mathrm{i}}$ : temperatur

dalam $=28-3=25$
$\mathrm{Q}=48 \times 0,559 \times 25=670,8 \mathrm{~W}$

Beban Transmisi dari Atap

Dari gambar 4.2 didapat : fi $=6,72$

$\mathrm{W} / \mathrm{m}^{2} \mathrm{~K}$ dan fo $=22,4 \mathrm{~W} / \mathrm{m}^{2} \mathrm{~K}$ maka

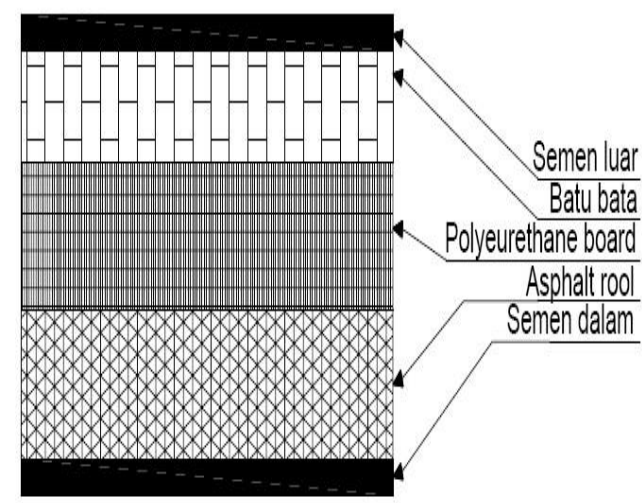

Gambar 3. Konstruksi atap

Dengan persamaan :

$\mathrm{Q}=\mathrm{A} \times \mathrm{U} \times \Delta \mathrm{T}$

Sehingga diperoleh :

$$
\begin{aligned}
U & =\frac{1}{\frac{1}{22,4}+\frac{0,0005}{31,5}+\frac{0,075}{0,046}+\frac{0,0005}{31,5}+\frac{1}{6,72}} \\
& =0,549 \mathrm{~W} / \mathrm{m}^{2} \mathrm{~K}
\end{aligned}
$$

\section{Luas Atap}

$\mathrm{L}\left(\right.$ atap) $\quad=\mathrm{p} \times 1=5 \times 3=15 \mathrm{~m}^{2}$ $\mathrm{Q} \quad=15 \times 0,549 \times 25=$ $205,88 \mathrm{~W}$

\section{Beban Transmisi dari Lantai}

Dari gambar 4.3 didapat : $\mathrm{fi}=9,24$ $\mathrm{W} / \mathrm{m}^{2} \mathrm{~K}$

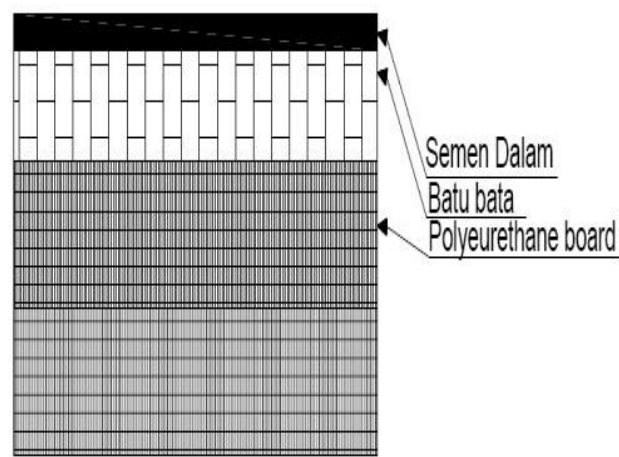

Gambar 4. Konstruksi lantai

Dengan persamaan :

$\mathrm{Q}=\mathrm{A} \times \mathrm{U} \times \Delta \mathrm{T}$

Sehingga diperoleh :

$U=\frac{1}{\frac{1}{22,4}+\frac{0,0005}{31,5}+\frac{0,075}{0,046}+\frac{0,0005}{31,5}+\frac{1}{9,24}}$ 
$=0,571 \mathrm{~W} / \mathrm{m}^{2} \mathrm{~K}$

Luas Lantai :

$\mathrm{L}$ (lantai) $\quad=\mathrm{p} \times 1=5 \times 3=15 \mathrm{~m}^{2}$

$\mathrm{Q} \quad=15 \times 0,571 \times 25=$

$214,13 \mathrm{~W}$

Qtotal trans $=670,8+205,88+$ $214,13=1090,73 \mathrm{~W}$

\section{Perhitungan Beban Infiltrasi}

Volume cold storage $=45^{\mathrm{m} 3}$ Dengan rata-rata didapat pertukaran udara 14.0 kali untuk 24 jam Dari tabel 2.3 didapat beban pertukaran udara untuk temperature dalam ruang cold storage dan kondisi luar cold storage dengan temperature $\pm 28{ }^{\circ} \mathrm{C}$ adalah $28 \mathrm{kkal} / \mathrm{m}$. $Q_{i}$

$$
\begin{aligned}
= & \frac{\mathrm{v}+\text { pertukaran udara } 24 \mathrm{jam}+\text { heat gain }}{24 \mathrm{jam}} \\
= & \frac{45+14,0+28}{24 \mathrm{jam}} \\
= & 735 \mathrm{kkal} / \mathrm{h}=0,854 \mathrm{~kW}=854 \mathrm{~W}
\end{aligned}
$$

Sehingga diperoleh:

$$
\begin{aligned}
Q_{\text {Ekternal }} & =\mathrm{Q}_{\text {Transmisi ruangan }}+\mathrm{Q}_{\text {Infiltasi }} \\
& =1090,73+854 \\
& =1944,73 \text { Watt }
\end{aligned}
$$

\section{Desain Model Kompresor}

Berdasarkan asumsi di atas di tawarkan dua skenario model sistem refrigerasi yaitu :

1. Sistem dengan Penggunaan kompresor tunggal

2. Sistem dengan Penggunaan 2 kompresor

Parameter yang perlu dihitung dalam perencanaan kompresor adalah :

\section{Refrigerant effect (RE)}

Refrigerant effect adalah penambahan jumlah entalpi dari refrigerant di dalam evaporator. Ditentukan rumus:

$R E 1=\quad$ hfevaporator -

hgkondensor

\section{Laju aliran massa}

Laju aliran massa pada tiap kompresor pada perancangan ini adalah: $\mathrm{m}=$ RE/Qtotal,

\section{Kerja kompresi (W)}

Kerja kompresi ditentukan dengan rumus : $\mathrm{W}=\mathrm{hf}$ kond- $\mathrm{hfev}$ aporator

\section{Daya Kompresor}

Daya kompresor dibutuhkan untuk mensirkulasikan refrigerant $\mathrm{P}=\mathrm{m} \times \mathrm{W}$

\section{Analisa Teknis Model Kompresor Tunggal}

Model pertama ini dirancang dengan menggunakan satu kompresor seperti terlihat pada gambar 4.4. dan grafik Thermodynamic Refrigeration Cycle seperti pada gambar 4.5.
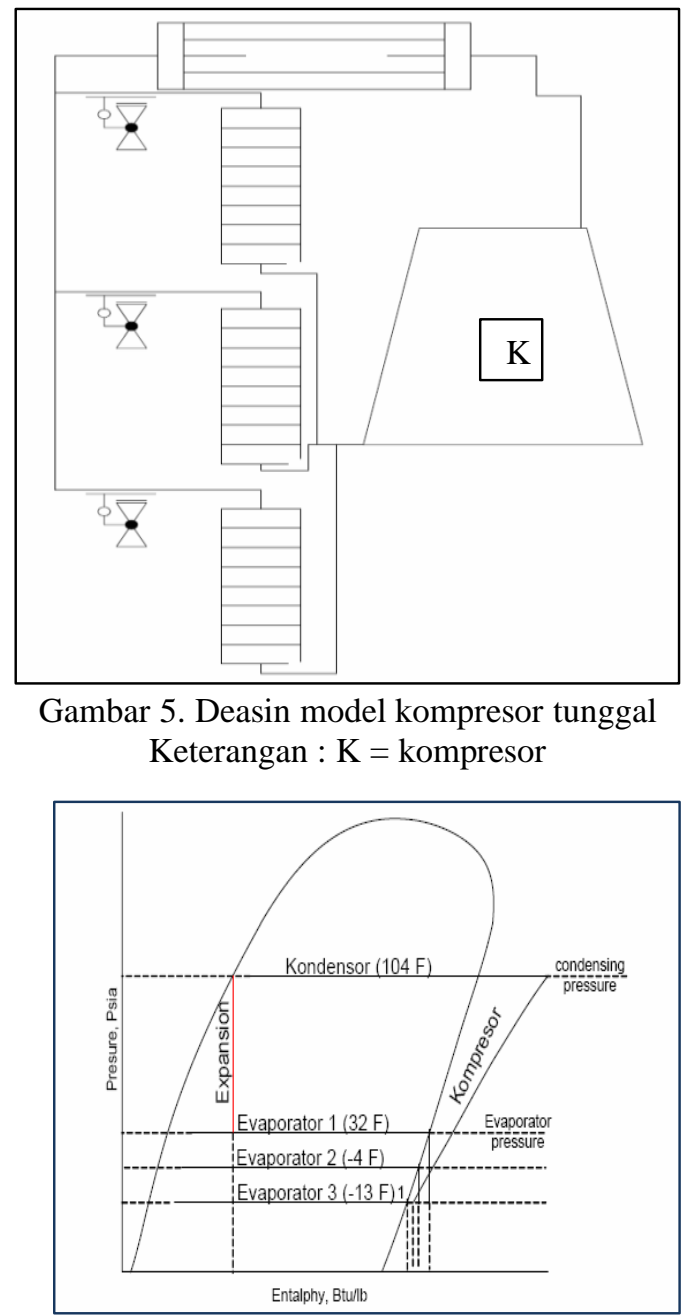

Gambar 6. grafik entalpi dengan satu kompresor

Berdasarkan gambar 4.5. grafik entalpi dengan satu kompresor,dari perhitungan diperoleh:

Perhitungan Tekanan, Suhu dan Entalpi 


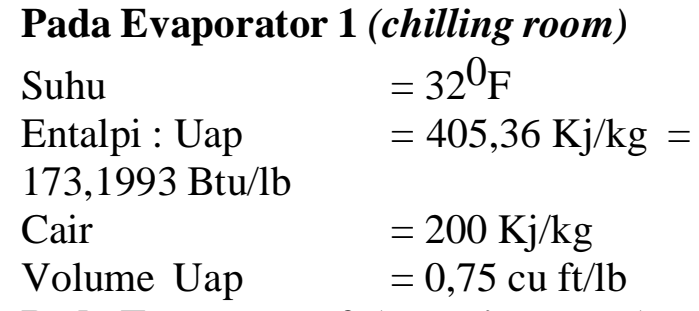

Pada Evaporator 2 (Freezing room)

\begin{tabular}{|c|c|}
\hline Suhu & $=-4^{0} \mathrm{~F}$ \\
\hline Entalpi : Uap & $=397,46 \mathrm{Kj} / \mathrm{kg}=$ \\
\hline $169,8238 \mathrm{Btu} / \mathrm{lb}$ & \\
\hline Cair & $=177,14 \mathrm{Kj} / \mathrm{kg}$ \\
\hline Volume Uap & $=1,42 \mathrm{cu} \mathrm{ft} / \mathrm{lb}$ \\
\hline Pada Evaporato & (Storage room) \\
\hline Suhu & $=-13^{0} \mathrm{~F}$ \\
\hline Entalpi : Uap & $=394,09 \mathrm{Kj} / \mathrm{kg}$ \\
\hline $168,3839 \mathrm{Btu} / \mathrm{lb}$ & \\
\hline Volume Uap & $=1,89 \mathrm{cu} \mathrm{ft} / \mathrm{lb}$ \\
\hline Pada Kondensor & \\
\hline Suh & $=104^{0} \mathrm{~F}$ \\
\hline Entalpi : Uap & $=416,56 \mathrm{Kj} / \mathrm{kg}$ \\
\hline Cair & $=249,68 \mathrm{Kj} / \mathrm{kg}$ \\
\hline Volume Uap & $=0,237 \mathrm{cu} \mathrm{ft} /$ \\
\hline
\end{tabular}

Kapasitas Refrigerasi

$\begin{array}{lll}\text { Evaporator 1 } & = & 276666,39 \\ \text { Btu/jam } & & \\ \begin{array}{l}\text { Evaporator 2 } \\ \text { Btu/jam }\end{array} & = & 470642,64 \\ \begin{array}{l}\text { Evaporator 3 } \\ \text { Btu/jam }\end{array} & = & 101782,35 \\ \text { Kapasitas } & & \end{array}$

\section{Kapasitas Kompresor}

Regrigerant Efek

$\begin{array}{lll}\mathrm{RE}_{1}=155,68 \mathrm{Kj} / \mathrm{kg} & = \\ 66,51782 \mathrm{Btu} / \mathrm{lb} & & \\ \mathrm{RE}_{2}=147,78 \mathrm{Kj} / \mathrm{kg} & = \\ 63,14236 \mathrm{Btu} / \mathrm{lb} & & \\ \mathrm{RE}_{3}=144,41 \mathrm{Kj} / \mathrm{kg}= \\ 61,70245 \mathrm{Btu} / \mathrm{lb}\end{array}$

Laju Aliran Massa

$$
\begin{array}{cl}
\mathrm{m}_{1} & =4159,2824 \mathrm{lb} / \mathrm{jam} \\
\mathrm{m}_{2} & =7453,833 \mathrm{lb} / \mathrm{jam} \\
\mathrm{m}_{3} & =1649,7294 \mathrm{lb} / \mathrm{jam} \\
\text { Total } & =13265,845 \mathrm{lb} / \mathrm{jam} \\
\text { Power } & =121075 \mathrm{Btu} / \mathrm{jam}
\end{array}
$$

Model pertama satu kompresor daya total kompresor yang dibutuhkan adalah : 121075 Btu/jam

\section{Analisa Teknis Model dengan dua kompresor}

Sistem didesain menggunakan sistem refrigerasi mekanik dengan tiga tahapan pendinginan/pembekuan (chilling, freezer, dan.storage), maka system ini didesain memakai kompresor yang berjumlah 2 buah dengan menggunakan system expansion valve, direncanakan sebuah kompresor mengkompresikan refrigerant R22 yang dioperasikan pada suhu kondensasi $104{ }^{0} \mathrm{~F}$ dan suhu evaporasi $32^{0} \mathrm{~F},-4^{0} \mathrm{~F},-13^{0} \mathrm{~F}$. Jumlah kompresor yang direncanakan berjumlah 3 buah dengan menggunakan individual expansion valve (gambar 4.6), dari data tersebut dapat dibuat grafik

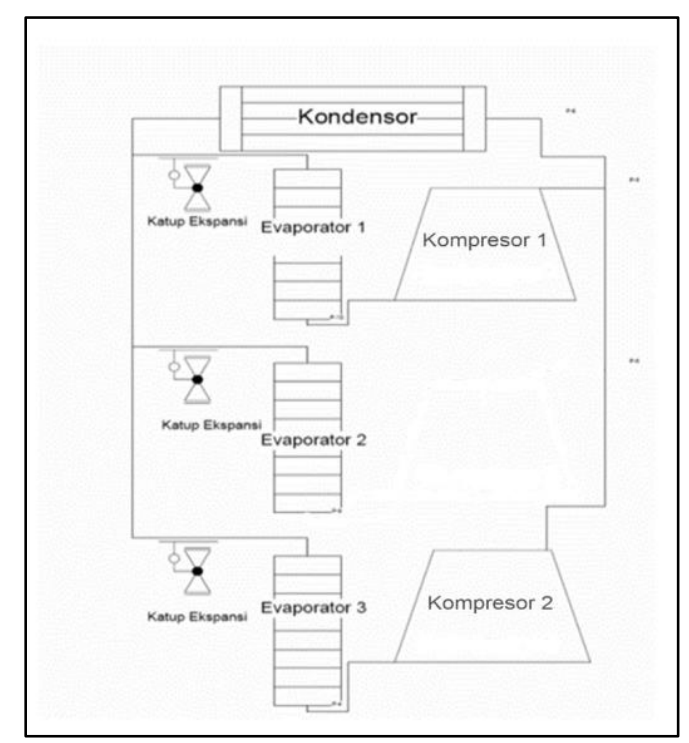

Thermodynamic Refrigeration Cycle seperti

Gambar 7. Desain model dua kompresor

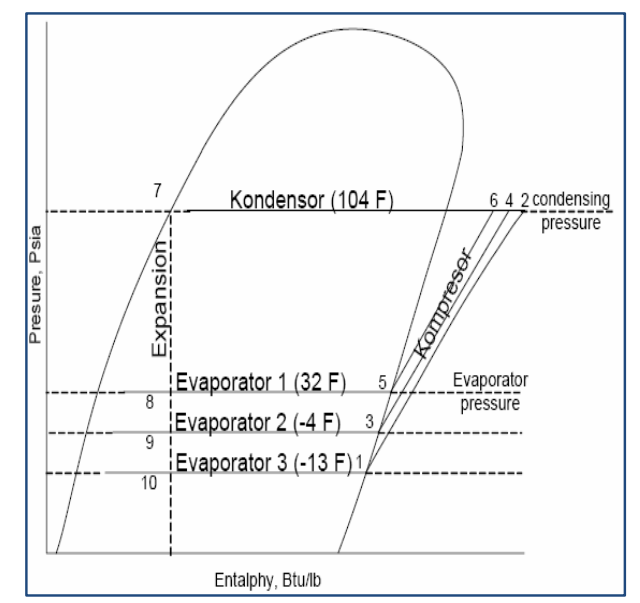

Gambar 8. grafik entalpi dengan dua kompresor 
Berdasarkan gambar 4.7 grafik entalpi sistem dengan dua kompresor, dari perhitungan diperoleh :

Perhitungan Tekanan, Suhu dan Entalpi

Pada Evaporator 1 (chilling room)

\begin{tabular}{|c|c|}
\hline Suhu & $=32^{0} \mathrm{~F}$ \\
\hline $\begin{array}{l}\text { Entalpi : Uap } \\
173 \text { 1993 Btw/lh }\end{array}$ & $=405,36 \mathrm{Kj} / \mathrm{kg}$ \\
\hline Cair & $=200 \mathrm{Kj} / \mathrm{kg}$ \\
\hline Volume Uap & $=0,75 \mathrm{cu} \mathrm{ft} / \mathrm{lb}$ \\
\hline Pada Evaporato & (Freezing room) \\
\hline Suhu & $=-4^{0} \mathrm{~F}$ \\
\hline $\begin{array}{l}\text { Entalpi : Uap } \\
169,8238 \mathrm{Btu} / \mathrm{lb}\end{array}$ & $=397,46 \mathrm{Kj} / \mathrm{kg}$ \\
\hline Cair & $=177,14 \mathrm{Kj} / \mathrm{kg}$ \\
\hline Volume Uap & $=1,42 \mathrm{cu} \mathrm{ft} / \mathrm{lb}$ \\
\hline
\end{tabular}

Pada Evaporator 3 (Storage room)

Suhu $=-13^{0} \mathrm{~F}$

Entalpi : Uap $=394,09$

$\mathrm{Kj} / \mathrm{kg}=168,3839 \mathrm{Btu} / \mathrm{lb}$

Volume Uap $\quad=1,89 \mathrm{cu} \mathrm{ft} / \mathrm{lb}$

Pada kondensor

Suhu $=104^{0} \mathrm{~F}$

Tekanan: Uap

$=224,6 \mathrm{Psi}$

Cair

$=209,9$ Psi

Entalpi : Uap

113,16 Btu/lb

$=416,56 \mathrm{Kj} / \mathrm{kg}=$

Cair

$=249,68 \mathrm{Kj} / \mathrm{kg}=$

42,32 Btu/lb

Volume Uap

\section{Kapasitas Refrigerasi}

$\begin{array}{lll}\text { Evaporator 1 } & = & 276666,39 \\ \text { Btu/jam } & & \\ \begin{array}{l}\text { Evaporator 2 } \\ \text { Btu/jam }\end{array} & = & 470642,64 \\ \begin{array}{l}\text { Evaporator 3 } \\ \text { Btu/jam }\end{array} & = & 101782,35 \\ \text { Kapasisas } & & \end{array}$

Kapasitas Kompresor

Regrigerant Efek

$\begin{array}{lll}\mathrm{RE}_{1}=155,68 & \mathrm{Kj} / \mathrm{kg}= \\ 66,5178182 \mathrm{Btu} / \mathrm{lb} & & \\ \mathrm{RE}_{2}=197,46 & \mathrm{Kj} / \mathrm{kg}= \\ 84,3692727 \mathrm{Btu} / \mathrm{lb} & & \\ \mathrm{RE}_{3}=216,95 & \mathrm{Kj} / \mathrm{kg}= \\ 92,2968182 \mathrm{Btu} / \mathrm{lb} & & \end{array}$

Laju Aliran Massa

$\begin{array}{ll}\mathrm{m}_{1} & =4159,2824 \mathrm{lb} / \mathrm{jam} \\ \mathrm{m}_{2} & =5578,48397 \mathrm{lb} / \mathrm{jam} \\ \mathrm{m}_{3} & =1098,12132 \mathrm{lb} / \mathrm{jam}\end{array}$

Daya Kompresor

$\begin{array}{llr}\mathrm{P}_{1} & =65114,7 \mathrm{btu} / \mathrm{jam} \\ \mathrm{P}_{2} & = & 131189,7 \\ \text { btu/jam } & & \end{array}$

Total Daya Kompresor $=196304,4$ Btu/jam

\section{Aspek Ekonomis}

Dari hasil perhitungan teoritis ternyata ada perbedaan total daya kompresor yang dibutuhkan antara model satu kompresor dan tiga kompresor, pada model pertama satu kompresor daya total kompresor adalah : 121075 Btu/jam, sedangkan pada model kedua dengan dua kompresor daya total kompresor yang dibutuhkan adalah 196304,4 Btu/jam, berarti ada selisih sebesar 75229,4 Btu/jam atau 21,3 KW, secara ekonomis dengan memakai model dua kompresor maka dapat dilakukan penghematan sebesar : 21,3 KW x 24 jam x 365 hari. Disisi lain bila sistem dengan satu komprsesor, bila terjadi gangguan pada kompresor akan berpengaruh keseluruh sistem, sedangkan sistem yang menngunakan dua kompresor, bila terjadi gangguan pada salah satu komprsesor, kompresor dan sistem lainnya masih bisa berfungsi, ini juga memudahkan dalam merawat dan mereparasi bila terjadi gangguan. Penggunaan kompresor tunggal kelemahannya adalah daya yang dibutuhkan lebih besar, tetapi space yang dibutuhkan kecil, dengan menggunakan dua kompresor dalam satu sistem dan sikulus pendingin yang sama, dapat menurunkan kebutuhan daya sebesar $14 \%$ dari daya penggunaan kompresor tunggal (Jordan $\&$ priester, 1964). Selain itu penggunaan dua kompresor, membuat sistem ini dapat di redesain sesuai dengan kebutuhan. Dari hasil analisa teknis dan analisa ekonomis model pertama dengan dua kompresor memiliki beberapa keunggulan secara teknis maupun ekonomis seperti yang telah di jelaskan 
di atas, tetapi dari sisi konstruksi dan space mungkin kompresor sistem tunggal lebih baik.

\section{KESIMPULAN}

Dari data yang didapat setelah melakukan pengujian dapat disimpulkan

1. Hasil analisa menunujukan bahwa desain sistem dengan menggunakan kompresor tunggal dan dua kompresor dengan sistem expansion valve masing-masing mempunyai keuntungan dan kerugian secara teknis maupun ekonomis.

2. Dari sisi ekonomis dan kebutuhan redesain sistem dua kompresor dengan sistem expansion valve ternyata lebih ekonomis karena membutuhkan daya yang lebih sedikit (selisih 21,3 KW dengan model kompresor tunggal) dan mudah di redesain sesuai kebutuhan, tapi dari sisi konstruksi dan space tipe kompresor tunggal mungkin lebih menguntungkan.

\section{REFERENSI}

[1] Jurnal Al ulum Sains dan Teknologi. Jainal Arifin, Optimasi Shell and Tube Kondensor dan Pemanfaatan Energi Panas Terbuang Pada AC untuk Pemanas air. Vol 1, No 1, November 2015

[2] Jurnal Ilmu dan Aplikasi Teknik, Marno, Awal Nurahmadi, Kajian Alat Penukar Kalor Shell And Tube Menggunakan Program Heat Transfer Research Inc (HTRI). Volume 2 No.1, Januari 2017

[3] Jurnal Kajian Teknik Mesin. Audri Deacy Cappenberg. Analisa Kinerja Alat Penukar Kalor Jenis Pipa Ganda. Vol. 1 No. 2.

[4] Artikel Teknik Mesin. Sugiyanto. Analisis Alat Penukar Kalor Tipe Shell And Tube Dan Aplikasi Perhitungan Dengan Microsoft Visual Basic 6.0. Universitas Gunadarma. Depok.
[5] Artikel Teknik Fisika. M. Fahmi Rizal, Gunawan N, Ir. Sarwono. Rancang Bangun Perangkat Lunak untuk Desain Alat Penukar Panas Tipe Shell dan Tube. ITS. Surabaya.

[6] Prosiding ITS. Grasiano Warakano dan Lailossa. Analisa Perbandingan Penggunaaan Kompresor Tunggal dan Tiga kompresor dengan sistem individual expansion valve untuk Cold Storage kapasitas 50 Ton untuk Pasar Ikan Lokal di Pulau Ambon. Surabaya 2009.

[7] Kreith, Frank. 1986. Prinsip-prinsip Perpindahan Panas. Edisi Ketiga. Erlangga: Jakarta.

[8] Sitompul, Tunggal M. 1993. Alat Penukar Kalor. Raja Grafindo Persada. 